\title{
Is the Second Sodium Pump Electrogenic?
}

\author{
L. E. Thomas, M. A. Rocafull, and J. R. del Castillo \\ Laboratorio de Fisiología Molecular, Centro de Biofísica y Bioquímica, Instituto Venezolano de Investigaciones Científicas (IVIC), \\ Apartado 20632, Caracas 1020 Districo Capital, Venezuela
}

Correspondence should be addressed to J. R. del Castillo; jdelcas@ivic.gob.ve

Received 11 August 2012; Revised 11 November 2012; Accepted 22 November 2012

Academic Editor: Michael D. Coleman

Copyright (C) 2013 L. E. Thomas et al. This is an open access article distributed under the Creative Commons Attribution License, which permits unrestricted use, distribution, and reproduction in any medium, provided the original work is properly cited.

Transepithelial sodium transport is a process that involves active $\mathrm{Na}^{+}$transport at the basolateral membrane of the epithelial cell. This process is mediated by the $\mathrm{Na}^{+} / \mathrm{K}^{+}$pump, which exchanges 3 internal $\mathrm{Na}^{+}$by 2 external $\mathrm{K}^{+}$inducing a net charge movement and the second $\mathrm{Na}^{+}$pump, which transports $\mathrm{Na}^{+}$accompanied by $\mathrm{Cl}^{-}$and water. It has been suggested that this pump could also be electrogenic. Herein, we evaluated, in MDCK cells, the short-circuit current $\left(I_{\mathrm{sc}}\right)$ generated by these $\mathrm{Na}^{+}$pumps at the basolateral membrane of the epithelial cells, using amphotericin B as an apical permeabilizing agent. $\mathrm{In}^{-}{ }^{-}$-containing media, $I_{\text {sc }}$ induced by amphotericin B is totally inhibited by ouabain, indicating that only the electrogenic $\mathrm{Na}^{+} / \mathrm{K}^{+}$pump is detectable in the presence of $\mathrm{Cl}^{-}$. Electrogenicity of the second $\mathrm{Na}^{+}$pump can be demonstrated in $\mathrm{Cl}^{-}$-free media. The existence of a furosemide-sensitive component of $I_{\mathrm{sc}}$, in addition to an ouabain-sensitive one, was identified in absence of chloride. Passive $\mathrm{Cl}^{-}$movement associated with the function of the second $\mathrm{Na}^{+}$pump seems to be regulated by the pump itself. These results demonstrate that the second $\mathrm{Na}^{+}$pump is an electroneutral mechanism result from the stoichiometric movement of $\mathrm{Na}^{+}$and $\mathrm{Cl}^{-}$across the basolateral plasma membrane of the epithelial cell.

\section{Introduction}

In epithelia, the transcellular movement of sodium is a two-step process, which is dependent on cellular energy and involves the participation of transporters. The sodium ion enters the epithelial cell across the apical pole of the cell following its electrochemical gradient and is actively extruded across the basolateral plasma membrane. There is an apical electrogenic movement of sodium ions with no direct coupling to the movement of other solutes through sodium channels [1], in addition to the sodium movement coupled with water-soluble organic solutes, such as hexoses, and amino acids [2-4]. Moreover, there is a coupled movement of $\mathrm{Na}^{+}$and $\mathrm{Cl}^{-}$across the brush-border membrane that results from two processes located at the apical membranes of the epithelial cells, exchange of $\mathrm{Na}^{+}$and $\mathrm{H}^{+}$, and exchange of $\mathrm{Cl}^{-}$and $\mathrm{HCO}_{3}{ }^{-}$. The bicarbonate and hydrogen ions are formed intracellularly from $\mathrm{H}_{2} \mathrm{CO}_{3}$ generated by the action of carbonic anhydrase. The downhill movement of sodium leads to a loss of $\mathrm{H}^{+}$, through $\mathrm{Na}^{+} / \mathrm{H}^{+}$exchange. The two exchange systems are interrelated and controlled by the intracellular $\mathrm{pH}$ [5]. Finally, the sodium liberated into the cytoplasm is then actively pumped out of the cell across the basolateral plasma membrane, thus maintaining the electrochemical gradient for this ion across the plasma membrane of the epithelial cells. The active epithelial absorption of sodium is responsible for the maintenance of a small but significant transepithelial potential difference of $3-5 \mathrm{mV}$ (serosa positive), which drives diffusional flux of chloride and water from the mucosal to the serosal fluid, either across the tight junctions or possibly also across the cell. In the small intestine and the proximal tubule, the primary active $\mathrm{Na}^{+}$transport across the basolateral plasma membrane of the epithelial cells has been mainly attributed to the $\mathrm{Na}^{+} / \mathrm{K}^{+}$pump. However, in these epithelia, active $\mathrm{Na}^{+}$transport seems to be not exclusively mediated by the $\mathrm{Na}^{+} / \mathrm{K}^{+}$exchange pump. In the proximal tubule, two different mechanisms for sodium transport across the basolateral plasma membrane of the cell have been described and characterized [6-8]. One mechanism exchanges the intracellular sodium for the extracellular potassium, whilst the other actively expels sodium, the cation being followed passively by chloride and water. The first of these mechanisms is inhibited by ouabain, weakly inhibited by ethacrynic acid, and insensitive to furosemide and triflocin, whereas the 
second mechanism is refractory to ouabain but inhibited by ethacrynic acid, furosemide, and triflocin. Both mechanisms are dependent on cellular energy since both are suppressed by 2,4-dinitrophenol or anoxia and derive their energy from the hydrolysis of ATP. In the rabbit ileum, Nellans and Schultz [9] were unable to detect a direct relationship between the ouabain-sensitive $\mathrm{Na}^{+} / \mathrm{K}^{+}$exchange mechanism and the active transepithelial $\mathrm{Na}^{+}$transport. Additionally, they reported that the maintenance of cell volume did not appear to be dependent upon the ouabain-sensitive $\mathrm{Na}^{+} / \mathrm{K}^{+}$ pump. These results suggest the existence of $\mathrm{K}^{+}$-independent active $\mathrm{Na}^{+}$extrusion in the small intestine. In this sense, two different mechanisms for active $\mathrm{Na}^{+}$transport across basolateral plasma membrane have been described in this tissue [10]. These $\mathrm{Na}^{+}$transport mechanisms have been associated with two different ATPase activities, also present in both renal and intestinal tissues [11-15]. The $\mathrm{Na}^{+} / \mathrm{K}^{+}$ATPase activity that requires $\mathrm{K}^{+}$to function is inhibited by ouabain and vanadate but is insensitive to furosemide. In contrast, The $\mathrm{Na}^{+}$-ATPase does not require $\mathrm{K}^{+}$, is insensitive to ouabain, but inhibited by furosemide and vanadate. This $\mathrm{K}^{+}$-independent, ouabain-insensitive mechanism has been denominated as the second sodium pump and has been implicated in isosmotic cell volume regulation $[7,8]$. Recently, the intestinal $\mathrm{K}^{+}$-independent, ouabain-insensitive $\mathrm{Na}^{+}$-ATPase has been isolated, purified, and cloned [16], and its biochemical and physiological characteristics have been reviewed [17].

It is widely accepted that the $\mathrm{Na}^{+} / \mathrm{K}^{+}$pump is electrogenic. However, there are no conclusive evidences about the electrogenicity of the $\mathrm{K}^{+}$-independent, ouabain-insensitive $\mathrm{Na}^{+}$pump. In this sense, Proverbio and Whittembury [18], working with kidney cortex slices and measuring the cell's electrical potential during active $\mathrm{Na}^{+}$extrusion, in the presence of ouabain, were able to demonstrate the transfer of electric charges across the plasma membrane of the tubular cells mediated by an ethacrynic acid-sensitive mechanism, suggesting that the $\mathrm{Na}^{+}$transport by the second sodium pump could be electrogenic. In this paper, we evaluated this possibility using polarized epithelial cells grown on permeable supports and measuring short-circuit currents $\left(I_{\mathrm{sc}}\right)$ in the Ussing chambers. The use of amphotericin B to permeabilize the apical membranes of epithelial cells to small cations allowed us to measure the currents generated at the basolateral plasma membrane by the $\mathrm{Na}^{+}$pumps.

\section{Materials and Methods}

2.1. Materials. Media were prepared from deionized water $(18 \mathrm{M} \Omega-\mathrm{cm})$ and analytical grade reagents. Ouabain, furosemide, amphotericin B, Dulbecco's modified Eagle's medium (DMEM), penicillin/streptomycin, HEPES, and trypsin were from Sigma Chemical. Fetal calf serum (FCS) was from Life Technologies.

\subsection{Methods}

2.2.1. Cell Culture. Madin-Derby canine kidney (MDCK) cells (type II) from American Type Culture Collection were suspended in DMEM supplemented with 10\% FCS, glutamine $(2 \mathrm{mM})$, penicillin $(50 \mathrm{IU} / \mathrm{mL})$, and streptomycin $(50 \mathrm{mg} / \mathrm{mL})$ and were plated on Transwell permeable supports (with pore of $0.4 \mu \mathrm{m}$ and diameter of $12 \mathrm{~mm}$; Corning Incorporated) at a seeding density of $10^{6}$ cells $/ \mathrm{cm}^{2}$. Cells were maintained at $37^{\circ} \mathrm{C}$ in air-5\% $\mathrm{CO}_{2}$ until they reached confluence (typically on day 6-8 after plating). Formation of tight monolayers was tested by measuring transepithelial resistance and transepithelial potential difference.

2.2.2. Isolation of Cell Cultured Membrane Fraction. To determine the $\mathrm{Na}^{+}$-ATPase activity in MDCK cells, they were homogenized in cold solution A $(250 \mathrm{mM}$ sucrose, $20 \mathrm{mM}$ Tris- $\mathrm{HCl} \mathrm{pH} 7.2,1 \mathrm{mM}$ EDTA, and $1 \mathrm{mM}$ PMSF) and then centrifuged at $5000 \times \mathrm{g}$ for $10 \mathrm{~min}$ at $4^{\circ} \mathrm{C}$. Supernatant was ultracentrifuged at $100,000 \times \mathrm{g}$ for $1 \mathrm{~h}$ at $4^{\circ} \mathrm{C}$. The pellet, containing the microsomal fraction, was resuspended in $500 \mu \mathrm{L}$ of solution B (20 mM Tris- $\mathrm{HCl} \mathrm{pH} 7.25$ and $1 \mathrm{mM}$ PMSF) and the ATPase activities were immediately determined.

2.2.3. ATPase Activities' Determination. The ATPase activities were determined as described $[11,19]$ and expressed in nmol of phosphate liberated per mg of protein per minute. ATPase activity determined in the presence of $\mathrm{Mg}^{2+}$ alone is referred as $\mathrm{Mg}^{2+}$-ATPase. The difference in activity between the $\mathrm{Mg}^{2+}$-ATPase and in the presence of both magnesium and sodium is denoted as the $\mathrm{Na}^{+}$-ATPase. Both $\mathrm{Mg}^{2+}$ - and $\mathrm{Na}^{+}$-ATPases are insensitive to $1 \mathrm{mM}$ ouabain. The difference in activity, obtained in the presence of $\mathrm{Mg}^{2+}, \mathrm{Na}^{+}, \mathrm{K}^{+}$, and ouabain and the activity determined in the presence of $\mathrm{Mg}^{2+}$ $\mathrm{Na}^{+}$, and $\mathrm{K}^{+}$is considered to be due to the $\mathrm{Na}^{+} / \mathrm{K}^{+}$-ATPase.

2.2.4. Protein Determination. The membrane protein was determined as described [20], with bovine serum albumin as standard.

2.2.5. RNA Isolation and cDNA Synthesis. Total RNA was prepared from MDCK cell monolayer at $100 \%$ confluence. Single-strand cDNA was synthesized from $3 \mu \mathrm{g}$ of total RNA, using oligo $(\mathrm{dT})_{20}$ and the ThermoScript RT-PCR System (Invitrogen).

2.2.6. Identification of the ATNA Gene ( $\mathrm{Na}^{+}$-ATPase) in MDCK Cells. The mRNA expression of the $\mathrm{Na}^{+}-$ ATPase $\alpha$-subunit (atna) was determined by specific RT-PCRs as described [21], employing the primers NAS (5'-CTGCCTATCCT-TAAGCTGTCCA-3') and CAS (5'TCAAAGGACTTCCCAAGGTCAAACTGTG), at a final concentration of 400 and $200 \mathrm{nM}$, respectively. Polymerase chain reaction was carried out employing Platinum Taq DNA polymerase (Invitrogen). Cycling parameters were $94^{\circ} \mathrm{C}$ for $2 \mathrm{~min}$; followed by 32 cycles at $94^{\circ} \mathrm{C}$ for $1 \mathrm{~min}, 55^{\circ} \mathrm{C}$ for $1 \mathrm{~min}$, and $68^{\circ} \mathrm{C}$ for $1 \mathrm{~min}$; then followed by $68^{\circ} \mathrm{C}$ for $10 \mathrm{~min}$. The RT-PCR products were analyzed by $2 \%$ agarose gel electrophoresis and stained with $0.5 \mu \mathrm{g} / \mathrm{mL}$ of ethidium bromide. 


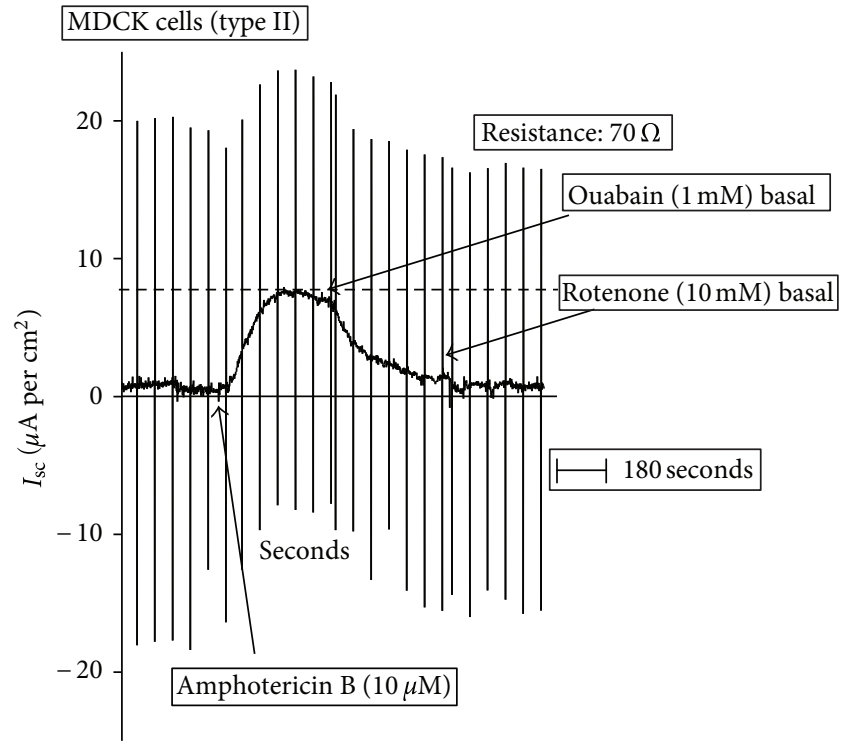

(a)

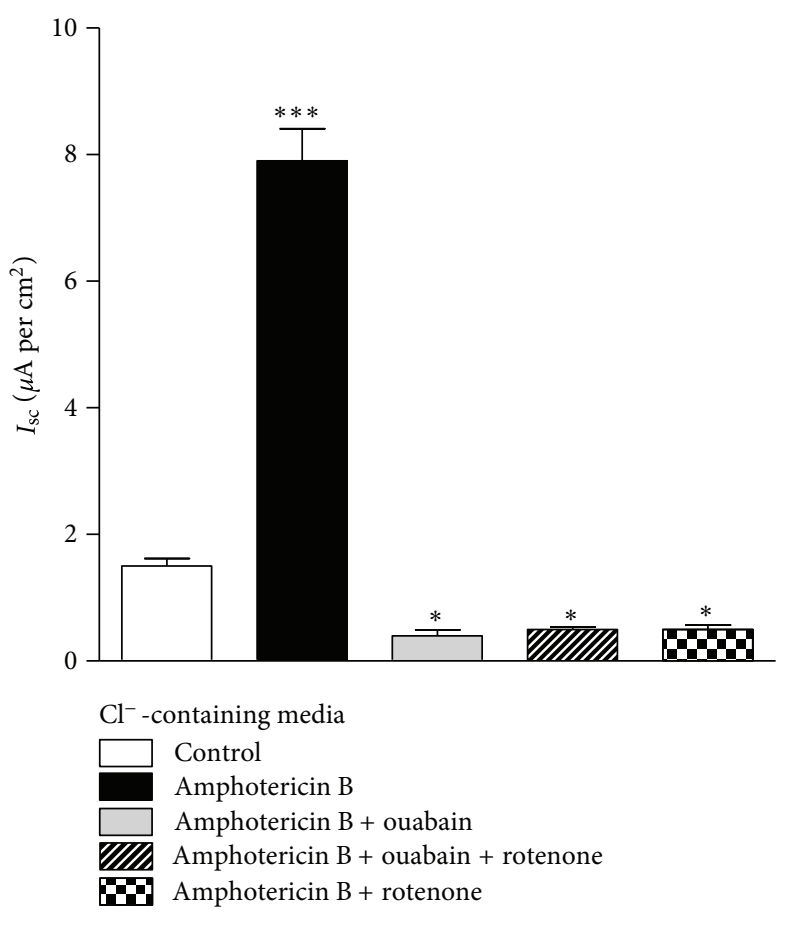

(b)

FIGURE 1: Short-circuit current $\left(I_{\mathrm{sc}}\right)$ in permeabilized MDCK cells: $\mathrm{Cl}^{-}$-containing media. (a) A typical record is shown to demonstrate the experimental protocol. After equilibration, amphotericin $\mathrm{B}(10 \mu \mathrm{M})$ was added to the apical medium, to permeabilize the apical plasma membrane to small cations. This maneuver allows measuring basolateral pump currents. Then, the effects of ouabain ( $1 \mathrm{mM})$ and rotenone $(10 \mu \mathrm{M})$ were evaluated. (b) Effect of ouabain $(1 \mathrm{mM})$ and rotenone $(10 \mu \mathrm{M})$ on $I_{\mathrm{sc}}$ of permeabilized MDCK cells. Results are mean \pm SEM of five independent experiments.

2.2.7. Electrical Measurements in the Ussing Chamber. Cell monolayers were typically used on days 6-8 after plating. Once mounted in the chamber, cell monolayers were bathed with media composed of (in $\mathrm{mM}$ ) $110 \mathrm{NaCl}, 5 \mathrm{KCl}, 7.5$ $\mathrm{K}_{2} \mathrm{SO}_{4}, 1 \mathrm{MgSO}_{4}, 1.6 \mathrm{CaCl}_{2}, 1 \mathrm{~K}_{2} \mathrm{HPO}_{4}, 10$ glucose, 5 glutamine, and $20 \mathrm{HEPES}, \mathrm{pH} 7.4$, at $25^{\circ} \mathrm{C}$. In the $\mathrm{Cl}^{-}$-free media, chloride was substituted by gluconate. To measure transport across the basolateral membranes, amphotericin B was added to the apical compartment at a final concentration of $10 \mu \mathrm{M}$. An automated voltage clamp unit (voltage-current clamp VCC 600, Physiological Instruments) was used to continuously monitor the transepithelial potential difference $(\mathrm{Pd})$ and the short-circuit current $\left(I_{\mathrm{sc}}\right)$. All measurements were made at $25^{\circ} \mathrm{C}$. Cell monolayers were kept under opencircuit conditions for about $15 \mathrm{~min}$ during equilibration to the medium. The epithelium was then short circuited by clamping the transepithelial potential to $0 \mathrm{mV}$, and $I_{\mathrm{sc}}$ was continuously displayed, digitized, and stored for analyses. A voltage pulse of $1 \mathrm{mV}$ during $1 \mathrm{sec}$ every $90 \mathrm{sec}$ was applied to the preparation to estimate the transepithelial resistance. Ouabain $(1 \mathrm{mM})$ was added to the basolateral side for inhibition of the $\mathrm{Na}^{+} / \mathrm{K}^{+}$-pump. Furosemide $(3 \mathrm{mM})$ was also added to the basolateral side for inhibition of the $\mathrm{Na}^{+}$ pump. Rotenone $(10 \mu \mathrm{M})$ was added to the basolateral side for metabolic inhibition.
2.2.8. Statistics. Results are presented as the means \pm SEM. The difference between means was evaluated by analysis of variance and considered significant at $P<0.05$.

\section{Results}

MDCK cell monolayers, cultured on Transwells, were studied under voltage-clamp conditions. As shown in Figure 1(a), under basal conditions, cells showed an $I_{\mathrm{sc}}$ of $0.95 \pm 0.09 \mu \mathrm{A}$ per $\mathrm{cm}^{2}$ with a transepithelial resistance of $70 \Omega \cdot \mathrm{cm}^{-2}$. Apical addition of $10 \mu \mathrm{M}$ amphotericin $\mathrm{B}$, which produces the permeabilization of the apical membrane to small cations, induced a significant increase in $I_{\mathrm{sc}}$ to $8.1 \pm 0.6 \mu \mathrm{A}$ per $\mathrm{cm}^{2}$ without any significant changes in transepithelial conductance. This increase was mostly abolished by the addition of ouabain $(1 \mathrm{mM})$ to the basal side of the epithelium. The subsequent addition of rotenone $(10 \mu \mathrm{M})$, a metabolic inhibitor, did not produce any further inhibition. Moreover, the addition of rotenone to the preparation before ouabain also abolishes the $I_{\mathrm{sc}}$ generated by the permeabilization of the apical membrane with amphotericin B (Figure 1(b)). To confirm that amphotericin B exerts its effect increasing intracellular $\mathrm{Na}^{+}$concentration, the effect of the drug was evaluated in MDCK cell monolayers incubated in $\mathrm{Na}^{+}$-free 
media, where $\mathrm{Na}^{+}$was replaced by $\mathrm{N}$-methyl glucamine ${ }^{+}$. Figure 2 presents a typical experiment where cells were incubated in $\mathrm{Na}^{+}$-free medium and $I_{\mathrm{sc}}$ determined. After a stabilization period, amphotericin $\mathrm{B}(10 \mu \mathrm{M})$ was added to the apical medium. Under this condition, amphotericin B did not produce any significant change in the $I_{\mathrm{sc}}$. Then, the apical medium was replaced by an $\mathrm{Na}^{+}$-containing $(50 \mathrm{mM})$ solution. This change induced a significant increase in $I_{\mathrm{sc}}$, which was totally inhibited by the addition of $0.5 \mathrm{mM}$ ouabain to the basolateral medium. At lower concentrations, ouabain $(0.25 \mathrm{mM})$ only produced partial inhibition. Notice that in $\mathrm{Na}^{+}$-containing media, without amphotericin $\mathrm{B}$, $I_{\text {sc }}$ is only $1.4 \pm 0.11 \mu \mathrm{A}$ per $\mathrm{cm}^{2}$. These results suggest that MDCK cells have only one electrogenic $\mathrm{Na}^{+}$-transport mechanism, which is sensitive to ouabain and located at the basolateral membrane. The characteristics of this mechanism are compatible with the $\mathrm{Na}^{+} / \mathrm{K}^{+}$pump. There is no evidence for electrogenicity of the second sodium pump under the studied conditions.

One possibility that could explain these results is the absence of the second sodium pump and its associated $\mathrm{Na}^{+}$ATPase in this preparation of MDCK cells. To confirm the existence of the $\mathrm{Na}^{+}$-ATPase in MDCK cells, the activity of the $\mathrm{K}^{+}$-independent, ouabain-insensitive $\mathrm{Na}^{+}$-ATPase activity and its corresponding mRNA atna (GI: 170524492) were determined in the preparation. As shown in Table 1 , microsomal fraction of MDCK cells has a basal $\mathrm{Mg}^{2+}$. dependent ATPase that is stimulated by $\mathrm{Na}^{+}$, with additional increase when $\mathrm{K}^{+}$was added to the incubation medium. This $\mathrm{K}^{+}$stimulation was totally inhibited by ouabain which is compatible with the presence of the ubiquitous $\mathrm{Na}^{+} / \mathrm{K}^{+}$ATPase. However, around a third of the $\mathrm{Na}^{+}$-stimulated ATPase was independent of $\mathrm{K}^{+}$, insensitive to ouabain, and totally inhibited by $3 \mathrm{mM}$ furosemide. These data indicate that the microsomal fraction of MDCK cells has an ATPase activity compatible with the $\mathrm{K}^{+}$-independent and ouabaininsensitive $\mathrm{Na}^{+}$-ATPase. The expression of the $\mathrm{Na}^{+}$-ATPase $\alpha$-subunit mRNA (atna) was verified in the MDCK cells under the experimental conditions described here, such as what was previously reported [16]. As shown in Figure 3, a specific DNA band of around $266 \mathrm{bp}$ was detected in the MDCK cells (lane 2) without any amplification from the PCR negative control (lane 3). The ouabain-insensitive $\mathrm{Na}^{+}$-ATPase from microsomal fraction of MDCK cells has been previously characterized [22]. This is a magnesiumdependent ATPase, specifically stimulated by $\mathrm{Na}^{+}$and inhibited by furosemide and vanadate. In addition, the enzyme is able to generate a phosphorylated intermediate. The specific stimulation by $\mathrm{Na}^{+}$, the inhibition by vanadate, and the formation of phosphorylated intermediary define this enzyme as a "P-type" ATPase.

Once the expression of $\mathrm{Na}^{+}$-ATPase was confirmed in this cell preparation, it emerges the possibility that the second sodium pump works as an electroneutral mechanism, coupling the active movement of sodium with a passive movement of $\mathrm{Cl}^{-}$through a conductive pathway, resulting in a stoichiometric $\mathrm{Na}^{+}$and $\mathrm{Cl}^{-}$transport across the basolateral plasma membrane of the cells. To evaluate this hypothesis,

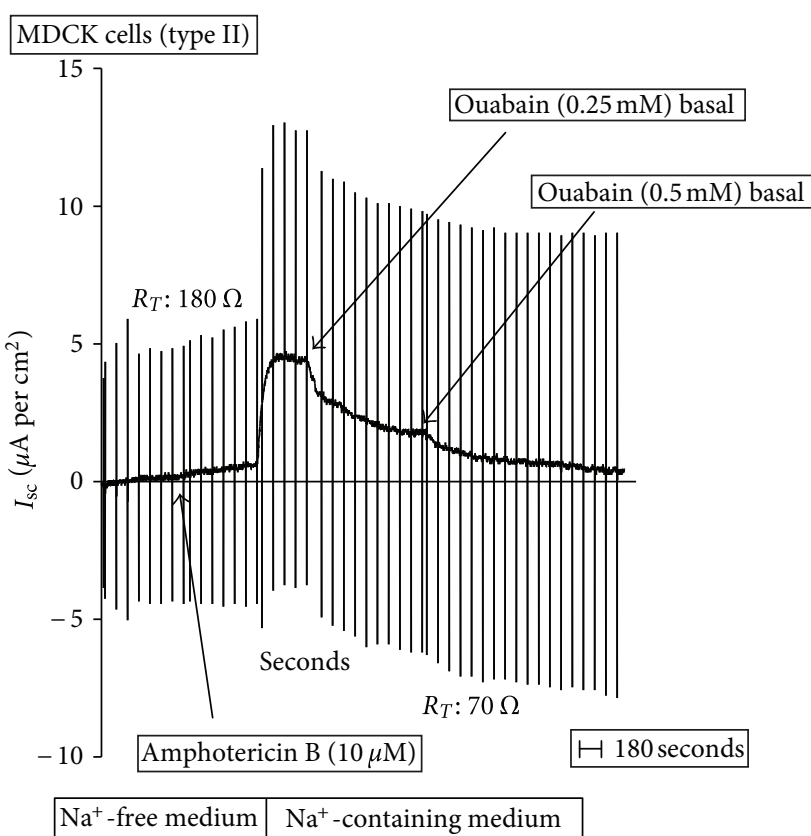

FIgURE 2: Short-Circuit current $\left(I_{\mathrm{sc}}\right)$ in permeabilized MDCK cells: $\mathrm{Na}^{+}$-free media. A typical record is shown to demonstrate the experimental protocol. After equilibration in $\mathrm{Na}^{+}$-free medium, amphotericin $\mathrm{B}(10 \mu \mathrm{M})$ was added to the apical solution, to permeabilize the apical plasma membrane to small cations. This maneuver allows measuring basolateral pump currents. Then, $\mathrm{Na}^{+}-$ free media was replaced by $\mathrm{Na}^{+}$-containing medium $(50 \mathrm{mM})$ and the effects of ouabain $(0.25$ and $0.5 \mathrm{mM})$ was evaluated.

the experiments were performed in media where $\mathrm{Cl}^{-}$was replaced by gluconate, a less permeable anion. In this case, cells were cultivated in $\mathrm{Cl}^{-}$-containing medium, and after the monolayer was $100 \%$ confluent, it was studied under voltage-clamp conditions, as described before. Results are shown in Figure 4. Under initial conditions, the $I_{\mathrm{sc}}$ was of $2.0 \mu \mathrm{A}$ per $\mathrm{cm}^{2}$ and the transepithelial resistance was $90 \Omega \cdot \mathrm{cm}^{-2}$. As expected, the $\mathrm{Cl}^{-}$substitution by gluconate in the apical medium induced an increase in the $I_{\mathrm{sc}}$ to $16.0 \mu \mathrm{A}$ per $\mathrm{cm}^{2}$ due to the diffusional flux of $\mathrm{Cl}^{-}$from the basolateral compartment to the apical one without changes in the transepithelial resistance. The substitution of $\mathrm{Cl}^{-}$in both sides returned the $I_{\mathrm{sc}}$ to $3.0 \mu \mathrm{A}$ per $\mathrm{cm}^{2}$ without changes in the transepithelial resistance. Under these conditions, the apical membrane was permeabilized to small cations by the addition of $10 \mu \mathrm{M}$ amphotericin $\mathrm{B}$, inducing an increase of $I_{\mathrm{sc}}$ to $16.4 \mu \mathrm{A}$ per $\mathrm{cm}^{2}$. The addition of ouabain $(1 \mathrm{mM})$ reduced the $I_{\mathrm{sc}}$ in $50 \%$ to $8.2 \mu \mathrm{A}$ per $\mathrm{cm}^{2}$. Subsequent addition of furosemide $(3 \mathrm{mM})$ abolished the $I_{\mathrm{sc}}$ in the $\mathrm{Cl}^{-}$-free media. After furosemide, the addition of rotenone did not produce any additional effect on the $I_{\mathrm{sc}}$. Rotenone $(10 \mu \mathrm{M})$ alone totally inhibited the $I_{\mathrm{sc}}$ induced by amphotericin B permeabilization (Figure 4(b)). The use of rotenone before the amphotericin $\mathrm{B}$ reduced the $I_{\mathrm{sc}}$ to zero and the subsequent permeabilization with the ionophore did not induce any current (data not shown). These results demonstrate that the second sodium pump is an electroneutral mechanism 
TABLE 1: ATPase activities of microsomal fraction from MDCK cells.

\begin{tabular}{lccc}
\hline Conditions & $\mathrm{Mg}^{2+}$ & $\mathrm{Mg}^{2+}+\mathrm{Na}^{+}$ & $\mathrm{Mg}^{2+}+\mathrm{Na}^{+}+\mathrm{K}^{+}$ \\
\hline Control & $49.25 \pm 1.65$ & $93.29 \pm 2.42$ & $183.88 \pm 10.31$ \\
Ouabain & $49.52 \pm 2.64$ & $90.73 \pm 3.33$ & $95.76 \pm 4.20$ \\
Ouabain + furosemide & $52.94 \pm 3.06$ & $53.26 \pm 3.30$ & $55.54 \pm 4.12$ \\
\hline
\end{tabular}

Results are expressed in nmoles Pi Lib./min $*$ mg of protein and represent mean \pm SEM of seven independent preparations.

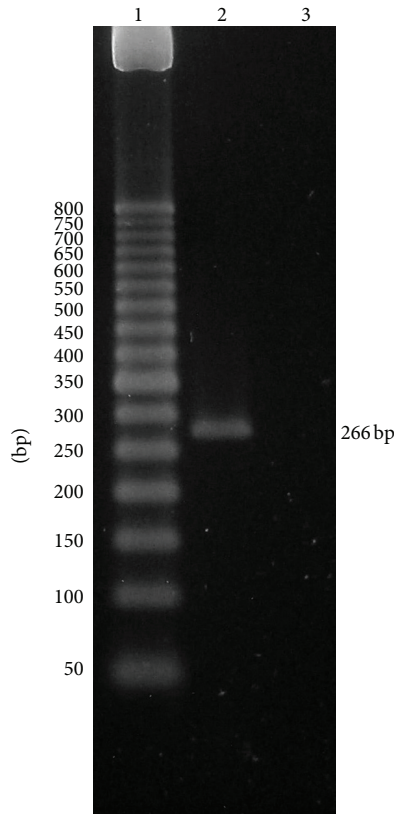

FIgURE 3: Expression of the $\mathrm{Na}^{+}$-ATPase mRNA in MDCK cells by RT-PCR. Expression of the homologous canine ATNA, corresponding to $\mathrm{Na}^{+}$-ATPase mRNA, was determined in MDCK cells by specific RT-PCR as described in the methods. PCR products were analyzed by electrophoresis in $2 \%$ agarose. The expected atna DNA band of $266 \mathrm{bp}$ was amplified from $1 \mu \mathrm{g}$ of MDCK total RNA (line 2). DEPC-treated water was used as negative control (line 3). The $50 \mathrm{bp}$ DNA ladder from Invitrogen was used as weight marker (lane $1)$.

resulting from the stoichiometry movement of $\mathrm{Na}^{+}$and $\mathrm{Cl}^{-}$ across the basolateral plasma membrane of the epithelial cell.

\section{Discussion}

In the proximal tubule and the small intestine, transepithelial sodium transport involves $\mathrm{Na}^{+}$entry across the apical membrane of the epithelial cell and the active exit through the basolateral membrane by two $\mathrm{Na}^{+}$pumps: the $\mathrm{Na}^{+} / \mathrm{K}^{+}$pump, which exchanges internal $\mathrm{Na}^{+}$by external $\mathrm{K}^{+}$, is inhibited by ouabain and is insensitive to furosemide; the second sodium pump, which extrudes $\mathrm{Na}^{+}$accompanied by $\mathrm{Cl}^{-}$and water (for review, see [17]). It has been well established that the $\mathrm{Na}^{+} / \mathrm{K}^{+}$pump is electrogenic due to the exchange of 3 internal $\mathrm{Na}^{+}$by 2 external $\mathrm{K}^{+}$[23]. The net movement of charges is not compensated by any passive movement of other ions across the plasma membrane. In the case of the second sodium pump, it has been proposed that the pump extrudes sodium by an electrogenic mechanism that induces the passive movement of $\mathrm{Cl}^{-}$to compensate the charge movement. The transport of $\mathrm{NaCl}$ would promote the osmotic transfer of water across the membrane and in this way regulate cell volume under isotonic conditions $[7,8,18]$.

The electrogenicity of these $\mathrm{Na}^{+}$pumps can be evaluated in epithelial cell monolayers, grown on Transwell and evaluated in the Ussing chambers under voltage-clamp conditions. This preparation represents a model of epithelium where the permeabilization of the apical membrane by ionophores permits the characterization of the electrical parameters of ion transport mechanisms located at the basolateral plasma membrane of the cell. Thus, the electrogenicity of the $\mathrm{Na}^{+} / \mathrm{K}^{+}$ pump has been evaluated in different cultured epithelial cells $[24,25]$. An important element in this model is the choice of the ionophore. For instance, amphotericin B is a natural antibiotic product of Streptomyces nodosus with fungicidal activity. This polyene molecule is also able to interact with the membranes of eukaryotic cells, forming aqueous pores or nonaqueous (cation-selective) channels. The formation of aqueous or nonaqueous pores depends on (a) the effective concentration of the drug and (b) the type of sterol in the membrane. The presence of ergosterol or cholesterol in the cell membrane determines the concentration at which aqueous or nonaqueous pores are formed. Lower concentrations are required to form nonaqueous pores. Membranes that contain ergosterol require lower amphotericin B concentration to form aqueous pores. The point has been recently reviewed by Cohen [26]. The capacity of polyene antibiotics (amphotericin B and nystatin) to form nonaqueous (cation-selective) channels in eukaryotic membranes has been used, since 1979, to selectively permeabilize the apical or basolateral plasma membrane of epithelial cells from a wide variety of tissues of different species, including cultured epithelial cells [24-32]. In 1986, Harvey and Lahlou [28] evaluated in detail, using intracellular microelectrodes, the effect of amphotericin B on the electrical resistances of the cell membrane and the paracellular pathway and the intracellular ionic activities in trout urinary bladder. Amphotericin B, added to the apical side of the epithelium, increases the transepithelial potential and the short-circuit current. The increases were sensitive to ouabain and dependent on apical $\mathrm{Na}^{+}$concentration. The apical membrane potential depolarized and its resistance fell significantly. At the same time, amphotericin B induced increase in intracellular $\mathrm{Na}^{+}$activity and decrease in $\mathrm{K}^{+}$ activity with a small change in $\mathrm{Cl}^{-}$intracellular activity, in agreement with their passive redistribution down their electrochemical gradients. These results demonstrate that the permeabilization of the apical membrane of epithelial 


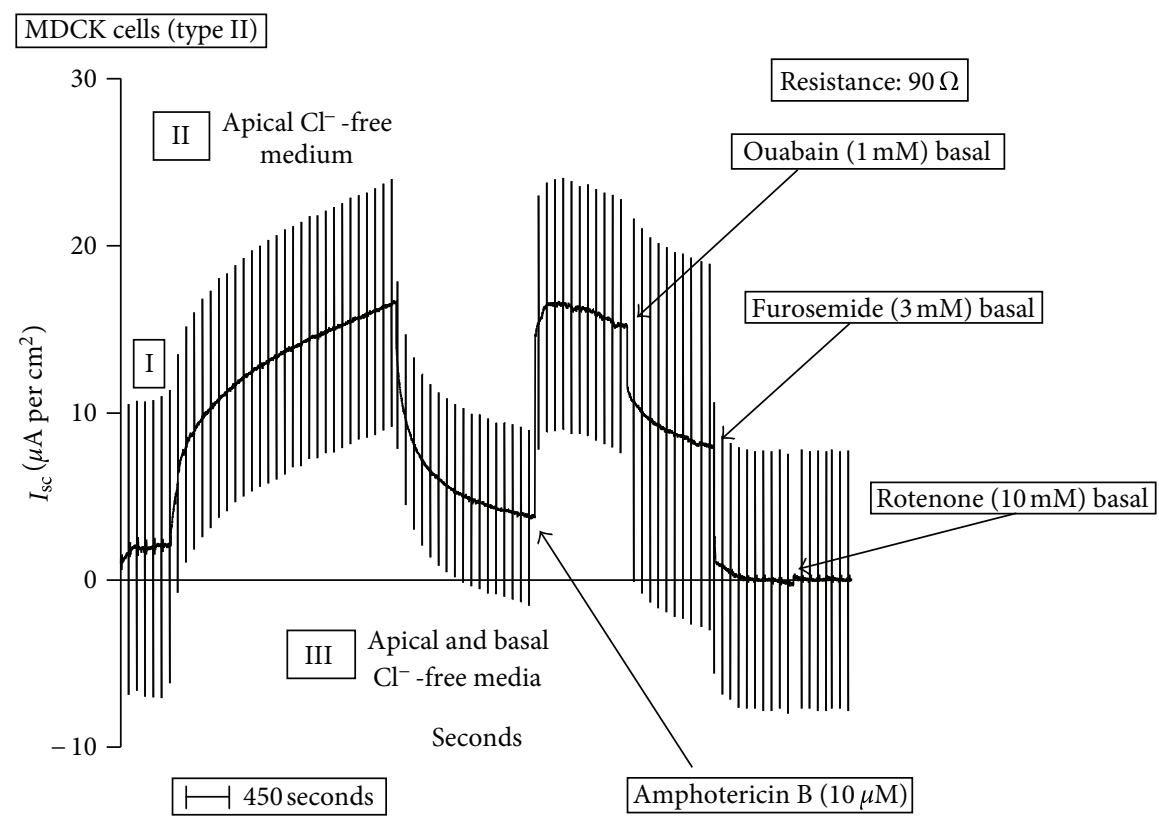

(a)

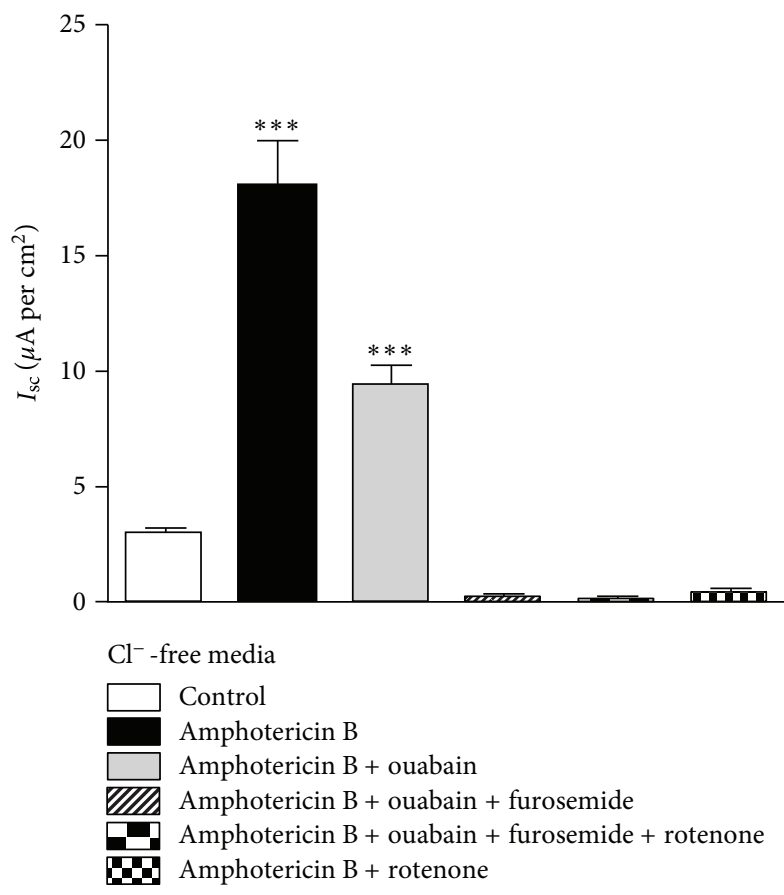

(b)

FIgURE 4: Short-circuit current $\left(I_{\mathrm{sc}}\right)$ in permeabilized MDCK cells: $\mathrm{Cl}^{-}$-free media. (a) A typical record is shown to demonstrate the experimental protocol. After equilibration (I), $\mathrm{Cl}^{-}$was sequentially removed from the apical (II) and basal sides (III) of the monolayer. Then, amphotericin B $(10 \mu \mathrm{M})$ was added to the apical medium, to permeabilize the apical plasma membrane. Next, the effects of ouabain $(1 \mathrm{mM})$, furosemide $(3 \mathrm{mM})$, and rotenone $(10 \mu \mathrm{M})$ were evaluated. (b) Effect of ouabain $(1 \mathrm{mM})$, furosemide $(3 \mathrm{mM})$, and rotenone $(10 \mu \mathrm{M})$ on $I_{\mathrm{sc}}$ of permeabilized MDCK cells. Results are mean \pm SEM of five independent experiments.

cells by amphotericin B induces increase in intracellular $\mathrm{Na}^{+}$ and decrease in intracellular $\mathrm{K}^{+}$concentrations. Additionally, they confirmed that the effect of the drug was $\mathrm{Na}^{+}$ dependent. Moreover, it was established that the increase in the transepithelial potential was due to the increase in the cell membrane electromotive forces, associated with the activation of the $\mathrm{Na}^{+} / \mathrm{K}^{+}$pump. The $\mathrm{Na}^{+}$dependence [33] and ouabain sensitivity [24] of the amphotericin B effects on epithelial electrical parameters have also been confirmed in cultured cells. 
In the present study, using this model, the electrogenicity of the $\mathrm{Na}^{+} / \mathrm{K}^{+}$pump was confirmed but the second sodium pump seems not to be electrogenic when $\mathrm{Cl}^{-}$is present in the medium. Under these conditions, all the current generated by the pumps across the basolateral plasma membrane of the MDCK cells is due to the $\mathrm{Na}^{+} / \mathrm{K}^{+}$pump, since it is totally inhibited by $1 \mathrm{mM}$ ouabain (Figure 1). The electrogenicity of the second sodium pump can be demonstrated only in the absence of the chloride. Under these conditions, the existence of a furosemide-sensitive $I_{\mathrm{sc}}$ current, in addition to an ouabain-sensitive one, was identified (Figure 4). The inhibition of the amphotericin B-induced $I_{\mathrm{sc}}$ by rotenone indicates that both mechanisms depend on cellular metabolism. Moreover, cyanide, a metabolic inhibitor that blocks the cytochrome oxidase, resembles the effect of rotenone on the amphotericin B-induced $I_{\mathrm{sc}}$ (data not shown). However, it is possible that rotenone could directly inhibit the $\mathrm{Na}^{+}$- and $\mathrm{Na}^{+} / \mathrm{K}^{+}$-ATPases. To discard this possibility, the effect of the drug on the ATPase activities present in a microsomal fraction of MDCK cells was evaluated. Membranes were incubated with rotenone $(10 \mu \mathrm{M})$ for 20 minutes at $4^{\circ} \mathrm{C}$ and the ATPases activities were determined as indicated in the methods. Rotenone has no effects on the ATPases present in the microsomal fraction.

The passive $\mathrm{Cl}^{-}$movement associated with the function of the second sodium pump seems to be regulated by the action of the pump itself. Thus, an electroneutral transport mode of the second sodium pump is observed in the presence of $\mathrm{Cl}^{-}$in the medium. In contrast, in the absence of this anion, the second sodium pump seems to be electrogenic, since a furosemide-sensitive $I_{\mathrm{sc}}$ becomes evident. These observations raise the question about how the $\mathrm{Cl}^{-}$movement is linked to the second sodium pump function. Chloride ions could move through an independent conductive pathway or form an integral element of the pump. In this sense, there are several lines of evidences indicating that the second sodium pump function does not require $\mathrm{Cl}^{-}$. The hydrolytic activity of the furosemide-sensitive $\mathrm{Na}^{+}$-ATPase is independent of the anion accompanying sodium $[11,16]$. In addition, the ATP-dependent $\mathrm{Na}^{+}$transport through the second sodium pump, in inside-out membrane vesicles [10] and isolated cells [8], is not affected by the total replacement of $\mathrm{Cl}^{-}$in the incubation medium, indicating that the function of the $\mathrm{Na}^{+}$ATPase do not depend on the presence of $\mathrm{Cl}^{-}$in the medium. Moreover, the modeled 3D structure of the $\mathrm{Na}^{+}$-ATPase, based on ATNA homology with other P-type ATPases, lacks transmembrane domains that resemble a chloride channel [17]. These evidences support the hypothesis that no $\mathrm{Cl}^{-}$ conductive pathway forms a part of the second sodium pump. However, $\mathrm{Cl}^{-}$transport associated with the second pump has been demonstrated in renal tissue and intestinal isolated cells $[7,8]$. Thus, renal and small intestinal epithelial cells are able to actively extrude $\mathrm{Na}^{+}, \mathrm{Cl}^{-}$, and water, even in the presence of ouabain. In contrast, the $\mathrm{Na}^{+}$extrusion, mediated by the $\mathrm{Na}^{+} / \mathrm{K}^{+}$pump, does not induce any $\mathrm{Cl}^{-}$nor water extrusion. These results demonstrate that a $\mathrm{Cl}^{-}$movement is associated with the active $\mathrm{Na}^{+}$transport mediated by the second sodium pump but the anion is not necessary to its function. The conductive movement of $\mathrm{Cl}^{-}$through the basolateral membrane of the epithelial cell seems regulated by the second sodium pump. An independent conductive pathway for $\mathrm{Cl}^{-}$should also affect the electrogenicity of the $\mathrm{Na}^{+} / \mathrm{K}^{+}$pump, but it is not the case in our experiments. The extent of the ouabain-sensitive $I_{\mathrm{sc}}$, an expression of the $\mathrm{Na}^{+} / \mathrm{K}^{+}$pump, is quite similar in the presence and absence of $\mathrm{Cl}^{-}$in the medium (Figures 1, 3, and 4), indicating that the electrogenicity of this pump is not affected by the presence of chloride. Finally, $I_{\mathrm{sc}}$ was also evaluated in cell monolayers preincubated with furosemide $(3 \mathrm{mM})$ and incubated in the absence of $\mathrm{Cl}^{-}$in the medium. Results were very similar to that observed in $\mathrm{Cl}^{-}$-containing media. The $I_{\mathrm{sc}}$ induced by amphotericin B permeabilization was totally inhibited by ouabain and its extend $(6.5 \pm 0.25 \mu \mathrm{A}$ per $\mathrm{cm}^{2}$ ) was comparable to that obtained in $\mathrm{Cl}^{-}$-containing media, supporting the view that the $I_{\text {sc }}$ mediated by the $\mathrm{Na}^{+} / \mathrm{K}^{+}$pump is not modified by the absence of $\mathrm{Cl}^{-}$in the medium. Our results demonstrate that the second sodium pump is an electroneutral mechanism resulting from the stoichiometry $\mathrm{Na}^{+}$and $\mathrm{Cl}^{-}$movement across the basolateral plasma membrane of the epithelial cell.

\section{Acknowledgments}

This work was partly supported by "Misión Ciencia" Grant 20070015856, Caracas, Venezuela. The authors thank Dr. Wilmer Rojas for his assistance.

\section{References}

[1] L. Schild, "The epithelial sodium channel and the control of sodium balance," Biochimica et Biophysica Acta, vol. 1802, no. 12, pp. 1159-1165, 2010.

[2] S. Bröer, "Amino acid transport across mammalian intestinal and renal epithelia," Physiological Reviews, vol. 88, no. 1, pp. 249-286, 2008.

[3] V. GN. Ganapathy and R. G. Martindale, "Protein digestion and absorption," in Physiology of Gastrointestinal Tract, L. Johnson, K. Barret, F. Gishan, J. Merchant, H. Said, and J. Wood, Eds., pp. 1667-1692, Academic Press, Meryland, Md, USA, 4th edition, 2006.

[4] E. Wright, D. Loo, B. Hirayama, and E. Turk, "Sugar absorption," in Physiology of Gastrointestinal Tract, L. Johnson, K. Barret, F. Gishan, J. Merchant, H. Said, and J. Wood, Eds., pp. 1653-1665, Academic Press, Meryland, Md, USA, 4th edition, 2006.

[5] P. R. Kiela, H. Xu, and F. K. Ghishan, "Apical $\mathrm{NA}^{+} / \mathrm{H}^{+}$ exchangers in the mammalian gastrointestinal tract," Journal of Physiology and Pharmacology, vol. 57, supplement 7, pp. 51-79, 2006.

[6] G. Whittembury, "Sodium and water transport in kidney proximal tubular cells," Journal of General Physiology, vol. 51, no. 5, pp. 303-314, 1968.

[7] G. Whittembury and F. Proverbio, "Two modes of Na extrusion in cells from guinea pig kidney cortex slices," Pflügers Archiv European Journal of Physiology, vol. 316, no. 1, pp. 1-25, 1970.

[8] J. R. del Castillo and G. Whittembury, " $\mathrm{Na}^{+}, \mathrm{K}^{+}$and $\mathrm{Cl}^{-}$ transport in isolated small intestinal cells from guinea pig. Evidences for the existence of a second $\mathrm{Na}^{+}$pump," Biochimica et Biophysica Acta, vol. 901, no. 2, pp. 209-216, 1987. 
[9] H. N. Nellans and S. G. Schultz, "Relations among transepithelial sodium transport, potassium exchange, and cell volume in rabbit ileum," Journal of General Physiology, vol. 68, no. 4, pp. 441-463, 1976.

[10] J. R. del Castillo and J. W. L. Robinson, " $\mathrm{Mg}^{2+}$-ATP-dependent sodium transport in inside-out basolateral plasma membrane vesicles from guinea-pig small intestinal epithelial cells," Biochimica et Biophysica Acta, vol. 812, no. 2, pp. 402-412, 1985.

[11] J. R. del Castillo and J. W. L. Robinson, " $\mathrm{Na}^{+}$-stimulated ATPase activities in basolateral plasma membranes from guinea-pig small intestinal epithelial cells," Biochimica et Biophysica Acta, vol. 812, no. 2, pp. 413-422, 1985.

[12] F. Proverbio and J. R. del Castillo, " $\mathrm{Na}^{+}$-stimulated ATPase activities in kidney basal-lateral plasma membranes," Biochimica et Biophysica Acta, vol. 646, no. 1, pp. 99-108, 1981.

[13] J. R. del Castillo, R. Marín, T. Proverbio, and F. Proverbio, "Partial characterization of the ouabain-insensitive, $\mathrm{Na}^{+}$-stimulated ATPase activity of kidney basal-lateral plasma membranes," Biochimica et Biophysica Acta, vol. 692, no. 1, pp. 61-68, 1982.

[14] F. Proverbio, M. Condrescu Guidi, and G. Whittembury, "Ouabain insensitive $\mathrm{Na}^{+}$stimulation of $\mathrm{AN} \mathrm{Mg}^{2+}$ dependent ATPase in kidney tissue," Biochimica et Biophysica Acta, vol. 394, no. 2, pp. 281-292, 1975.

[15] L. E. Thomas, L. Burguillos, and J. R. Del Castillo, "Backdoor phosphorylation of basolateral plasma membranes of small intestinal epithelial cells: characterization of a furosemideinduced phosphoprotein related to the second sodium pump," Archives of Biochemistry and Biophysics, vol. 419, no. 2, pp. 190-197, 2003.

[16] M. A. Rocafull, F. J. Romero, L. E. Thomas, and J. R. Del Castillo, "Isolation and cloning of the $\mathrm{K}^{+}$-independent, ouabain-insensitive $\mathrm{Na}^{+}$-ATPase," Biochimica et Biophysica Acta, vol. 1808, no. 6, pp. 1684-1700, 2011.

[17] M. A. Rocafull, F. J. Romero, L. E. Thomas, and J. R. Del Castillo, "The Second Sodium Pump: from the function to the gene," Pflugers Arch, vol. 463, pp. 755-777, 2012.

[18] F. Proverbio and G. Whittembury, "Cell electrical potentials during enhanced sodium extrusion in guinea pig kidney cortex slices," Journal of Physiology, vol. 250, no. 3, pp. 559-578, 1975.

[19] L. Cariani, L. Thomas, J. Brito, and J. R. del Castillo, "Bismuth citrate in the quantification of inorganic phosphate and its utility in the determination of membrane-bound phosphatases," Analytical Biochemistry, vol. 324, no. 1, pp. 79-83, 2004.

[20] K. G. Gadd, "Protein estimation in spinal fluid using Coomassie blue reagent," Medical Laboratory Sciences, vol. 38, no. 1, pp. 61-63, 1981.

[21] M. A. Rocafull, L. E. Thomas, G. J. Barrera, and J. R. del Castillo, "Differential expression of P-type ATPases in intestinal epithelial cells: identification of putative new atplal splice-variant," Biochemical and Biophysical Research Communications, vol. 391, no. 1, pp. 152-158, 2010.

[22] A. M. De Souza, T. L. G. Carvalho, P. M. Sabino et al., "Characterization and partial isolation of ouabain-insensitive $\mathrm{Na}^{+}$-ATPase in MDCK I cells," Biochimie, vol. 89, no. 11, pp. 1425-1432, 2007.

[23] J. H. Kaplan, "Biochemistry of Na,K-ATPase," Annual Review of Biochemistry, vol. 71, pp. 511-535, 2002.

[24] A. Dagenais, R. Fréchette, Y. Yamagata et al., "Downregulation of ENaC activity and expression by TNF- $\alpha$ in alveolar epithelial cells," American Journal of Physiology, vol. 286, no. 2, pp. L301-L311, 2004.
[25] H. Mairbäurl, K. Mayer, K. J. Kim, Z. Borok, P. Bärtsch, and E. D. Crandall, "Alveolar epithelial ion and fluid transport hypoxia: decreases active $\mathrm{Na}$ transport across primary rat alveolar epithelial cell monolayers," American Journal of Physiology, vol. 282, no. 4, pp. L659-L665, 2002.

[26] B. E. Cohen, "Amphotericin B membrane action: role for two types of ion channels in eliciting cell survival and lethal effects," Journal of Membrane Biology, vol. 238, no. 1-3, pp. 1-20, 2010.

[27] S. A. Lewis and N. K. Wills, "Apical membrane permeability and kinetic properties of the sodium pump in rabbit urinary bladder," Journal of Physiology, vol. 341, pp. 169-184, 1983.

[28] B. J. Harvey and B. Lahlou, "Ion-selective micro-electrode studies of the electrochemical potentials in trout urinary bladder," Journal of Physiology, vol. 370, pp. 467-488, 1986.

[29] K. U. Petersen and L. Reuss, "Cyclic AMP-induced chloride permeability in the apical membrane of Necturus gallbladder epithelium," Journal of General Physiology, vol. 81, no. 5, pp. 705-729, 1983.

[30] R. F. Husted, M. J. Welsh, and J. B. Stokes, "Variability of functional characteristics of MDCK cells," American Journal of Physiology, vol. 250, no. 2, part 1, pp. C214-C221, 1986.

[31] M. C. Broillet and J. D. Horisberger, "Basolateral membrane potassium conductance of A6 cells," Journal of Membrane Biology, vol. 124, no. 1, pp. 1-12, 1991.

[32] S. F. Hsu and R. R. Burnette, "Characterization of the effects of amphotericin B on ion channels in MDCK cells using the patchclamp technique," Biochimica et Biophysica Acta, vol. 1329, no. 1, pp. 26-38, 1997.

[33] J. Beron, L. Mastroberardino, A. Spillmann, and F. Verrey, "Aldosterone modulates sodium kinetics of Na,K-ATPase containing an $\alpha 1$ subunit in A6 kidney cell epithelia," Molecular Biology of the Cell, vol. 6, no. 3, pp. 261-271, 1995. 

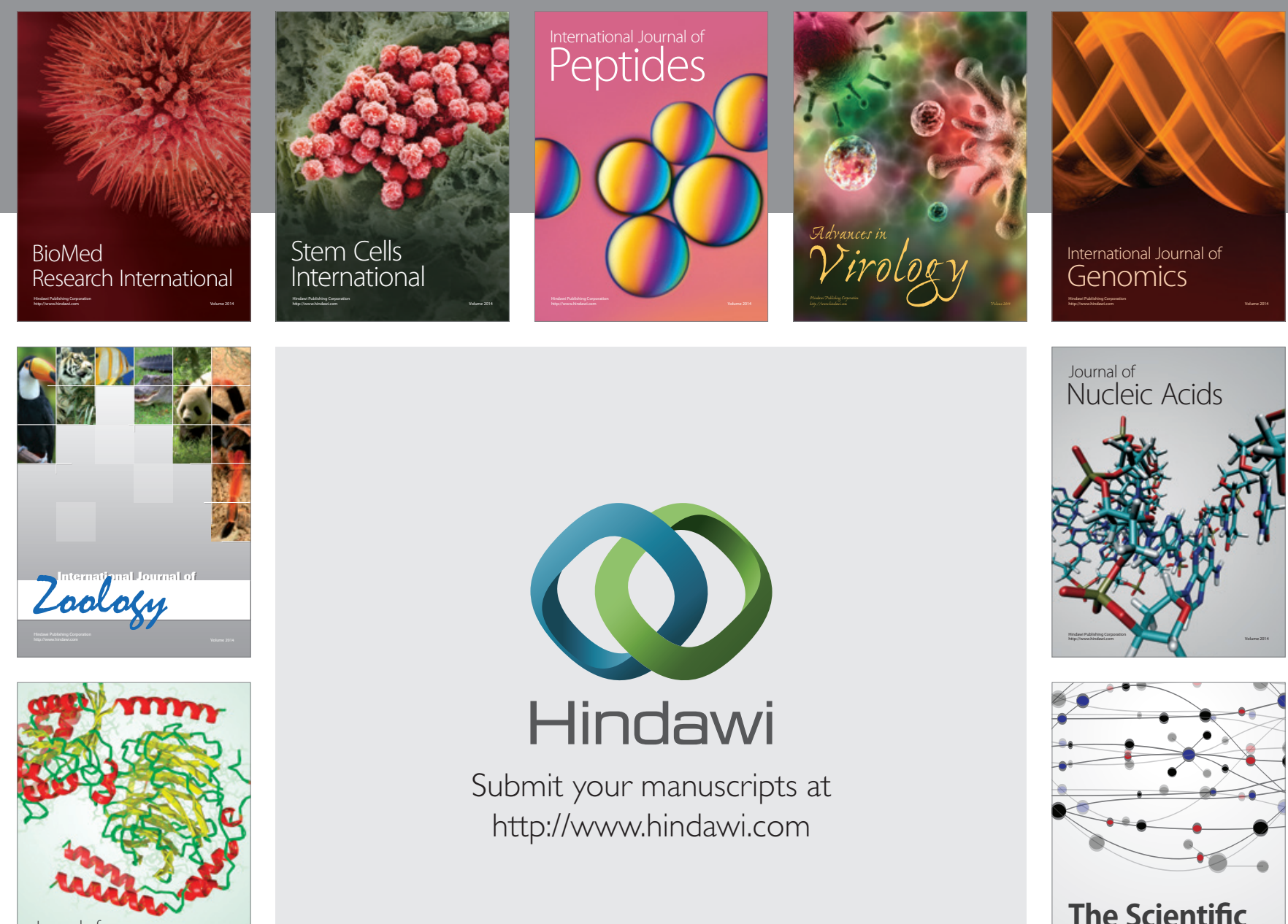

Submit your manuscripts at

http://www.hindawi.com

Journal of
Signal Transduction
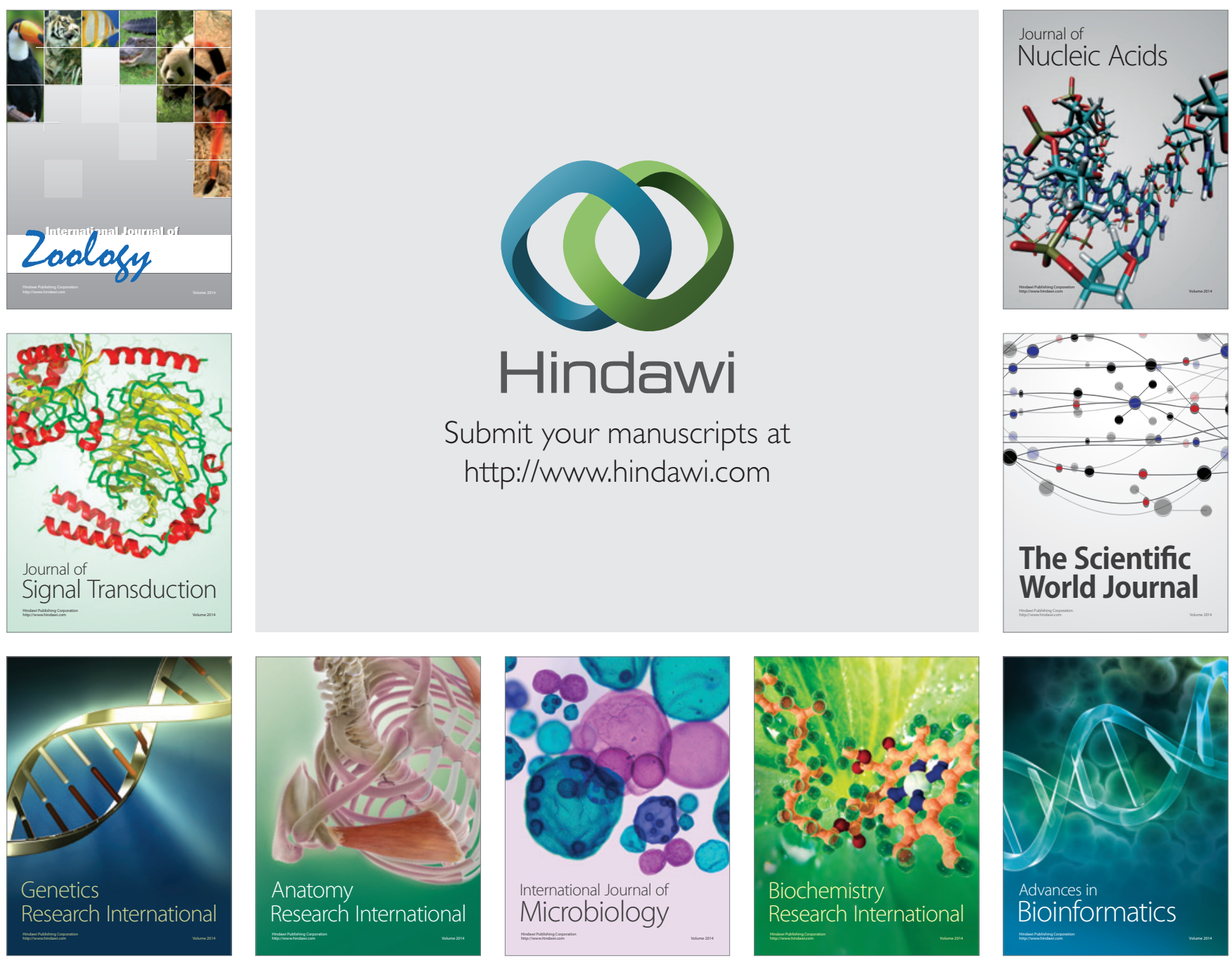

The Scientific World Journal
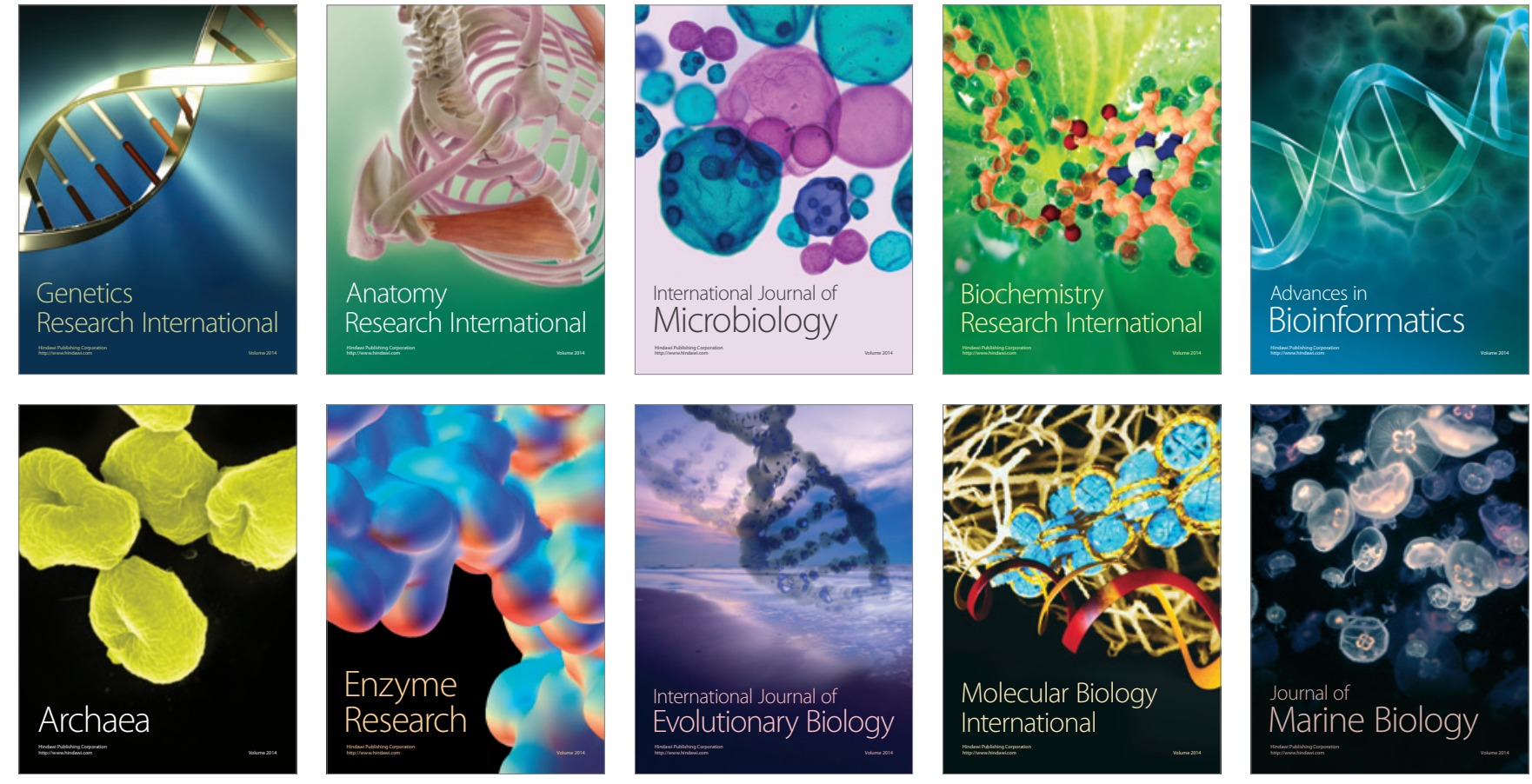